\title{
Adaptability and stability of white oat cultivars in relation to chemical composition of the caryopsis
}

\author{
Maraisa Crestani Hawerroth(1), Fernando Irajá Félix de Carvalho( ${ }^{(2)}$, Antonio Costa de Oliveira ${ }^{(2)}$, \\ José Antonio Gonzalez da Silva ${ }^{(3)}$, Luiz Carlos Gutkoski( ${ }^{(4)}$, João Francisco Sartori ${ }^{(5)}$, \\ Leomar Guilherme Woyann ${ }^{(2)}$, Rosa Lía Barbieri(6) and Fernando José Hawerroth ${ }^{(1)}$
}

\begin{abstract}
(1)Embrapa Agroindústria Tropical, Rua Dra. Sara Mesquita, no 2.270, Planalto do Pici, Caixa Postal 3.761, CEP 60511-110 Fortaleza, CE. E-mail: maraisacrestani@gmail.com, fernando.hawerroth@embrapa.br (2)Universidade Federal de Pelotas, Faculdade de Agronomia Eliseu Maciel, Departamento de Fitotecnia, Campus Universitário Capão do Leão, Caixa Postal 354, CEP $96010-900$ Pelotas, RS. E-mail: carvalho@ufpel.tche.br, acostol@terra.com.br, leowoyann@gmail.com (3)Universidade Regional do Noroeste do Estado do Rio Grande do Sul, Departamento de Estudos Agrários, Rua do Comércio, no 3.000, Bairro Universitário, CEP $98700-000$ ljuí, RS. E-mail: jagsfaem@yahoo.com.br ${ }^{(4)}$ Universidade de Passo Fundo, Centro de Pesquisa em Alimentação, Laboratório de Cereais, Campus I, Rodovia BR 285, Km 171, Bairro São José, Caixa Postal 611, CEP 99001-970 Passo Fundo, RS. E-mail: gutkoski@upf.br (5)Fundação Pró-sementes de Apoio à Pesquisa, Rua Diogo de Oliveira, no 640, CEP 99025-130 Passo Fundo, RS. E-mail: sartori@fundacaoprosementes.com.br ${ }^{(5)}$ Embrapa Clima Temperado, Rodovia BR 392, Km 78, Caixa Postal 403, CEP 96001-970 Pelotas, RS. E-mail: lia.barbieri@embrapa.br
\end{abstract}

\begin{abstract}
The objective of this work was to characterize the chemical properties of white oat (Avena sativa) caryopsis and to determine the adaptability and stability of cultivars recommended for cultivation in the state of Rio Grande do Sul, Brazil. The trials were carried out in the 2007, 2008 and 2009 crop seasons, in three municipalities: Augusto Pestana, Capão do Leão, and Passo Fundo. Fifteen cultivars were evaluated in a randomized block design, with four replicates. The contents of protein, lipid, and nitrogen-free extract were evaluated in the caryopsis. Cultivar performances for the measured characters varied according to location and year of cultivation. The cultivar URS Guapa showed high content of nitrogen-free extract and low contents of protein and lipid in the caryopsis. 'FAPA Louise' showed high content of lipid, whereas 'Albasul', 'UPF 15', and 'UPF 18' showed high content of protein and low content of nitrogen-free extract. There is no evidence of an ideal biotype for the evaluated characters, which could simultaneously show high average performance, adaptability to favorable and unfavorable environments, and stability.
\end{abstract}

Index terms: Avena sativa, bissegmented linear regression, lipid, nitrogen-free extract, nutritional quality, protein.

\section{Adaptabilidade e estabilidade de cultivares de aveia-branca quanto à composição química da cariopse}

Resumo - O objetivo deste trabalho foi caracterizar as propriedades químicas da cariopse de aveia-branca (Avena sativa) e determinar a adaptabilidade e estabilidade de cultivares recomendadas para cultivo no Rio Grande do Sul. Os ensaios foram realizados nas safras de 2007, 2008 e 2009, em três municípios: Augusto Pestana, Capão do Leão e Passo Fundo. Foram avaliadas 15 cultivares, em delineamento de blocos ao acaso, com quatro repetições. Foram determinados os teores de proteína, lipídeos e extrativos não nitrogenados na cariopse. O desempenho das cultivares quanto aos caracteres avaliados variou conforme o local e ano de cultivo. A cultivar URS Guapa apresentou elevado conteúdo de extrativos não nitrogenados na cariopse, e baixos de proteína e lipídeo. 'FAPA Louise' apresentou elevado conteúdo de lipídeo, enquanto que 'Albasul', 'UPF 15' e 'UPF 18' apresentaram elevado conteúdo de proteína e baixo teor de extrativos não nitrogenados. Não há evidência de um biótipo ideal para os caracteres avaliados, que apresente, simultaneamente, elevado desempenho médio, adaptabilidade a ambientes favoráveis e desfavoráveis, e estabilidade.

Termos para indexação: Avena sativa, regressão linear bissegmentada, lipídeo, extrativos não nitrogenados, qualidade nutricional, proteína.

\section{Introduction}

The environment tends to affect the contents of protein, lipid, and nitrogen-free extract in white oat (Avena sativa L.) caryopses (Beber et al., 2002; Zhu et al., 2004; Gatto, 2005; Peterson et al., 2005; Martinez et al., 2010). Due to the characteristically polygenic behavior detected in these characters ( $\mathrm{Zhu}$ et al., 2004; Orr \& Molnar, 2007; Crestani et al., 2012), the genotype $\mathrm{x}$ environment $(\mathrm{G} \times \mathrm{E})$ interaction does not 
provide a deep understanding of genotype performance in different environmental conditions. The analysis of stability and adaptability allows the identification of genotypes responsive to environmental variations and with predict performance (Cruz et al., 2004).

Among available methods to identify the adaptability and stability of genotypes, the one proposed by Cruz et al. (1989) is usually adopted for evaluation of annual species, tested in several environments (more than eight). This method has been adopted to evaluate grain yield of white oat genotypes in different environments and cultivation schemes (Lorencetti et al., 2002, 2004). According to this model, adaptability and stability are established based on bissegmented linear regressions, in which the dependent variable is expressed as an index that measures the quality of the evaluated environments. According to Cruz et al. (1989), the ideal genotype should have high average performance, adaptability to favorable and unfavorable environments, and regression deviations equal to zero (stability).

Considering the chemical attributes of oat caryopsis, genotypes with grains suitable for human diet should have low calory, low contents of lipid and nitrogen-free extract, and high contents of protein and dietary fiber (Holland, 1997; Chernyshova et al., 2007). For feedstuffs, however, genotypes should have high calory, characterized by high contents of lipid, protein, and nitrogen-free extract (Holland, 1997; Marinissen et al., 2004). The fraction of nitrogen-free extract corresponds to nonstructural carbohydrates in the caryopsis, mainly starch, sucrose, and pectin. The understanding of the $\mathrm{G} \times \mathrm{E}$ interaction for caryopsis chemical quality of white oat cultivars is very important for their proper recommendation, aiming at the production of high-quality grains, destined for specific market niches. Moreover, the estimates of environment effects on cultivar phenotypic expression is essential to direct future selection strategies of superior white oat genotypes for chemical quality of grains.

The objective of this work was to characterize the chemical properties of white oat (Avena sativa) caryopsis, in relation to protein, lipid and nitrogen-free extract contents, and to determine the adaptability and stability of cultivars recommended for cultivation in the state of Rio Grande do Sul, Brazil, regarding these characteres.

\section{Materials and Methods}

Fifteen white oat cultivars, recommended for cultivation in the state of Rio Grande do Sul, Brazil, were evaluated during the crop seasons of 2007, 2008, and 2009. The trials were carried out in the municipalities Augusto Pestana $\left(28^{\circ} 27^{\prime} \mathrm{S}, 53^{\circ} 54^{\prime} \mathrm{W}, 328-\mathrm{m}\right.$ altitude), in a Rhodic Hapludox (Latossolo Vermelho distrófico, according to Santos et al., 2006); in Capão do Leão ( $31^{\circ} 45^{\prime} \mathrm{S}, 52^{\circ} 29^{\prime} \mathrm{W}, 13-\mathrm{m}$ altitude), in a Typic Hapludox (Latossolo Vermelho-Amarelo); and in Passo Fundo $\left(28^{\circ} 15^{\prime} \mathrm{S}, 52^{\circ} 24^{\prime} \mathrm{W}\right.$, altitude $\left.687 \mathrm{~m}\right)$, in a Rhodic Hapludox. All trials were performed in a randomized block design, with four replicates. A density of 250 viable seeds per square meter was used. Replicates were formed by plots with five 5.0-m rows, spaced in $0.20 \mathrm{~m}$, with measurements made in the three core lines. Soil preparation, liming, and fertilization were made following the recommendations for white oat in Brazil (Comissão Brasileira de Pesquisa de Aveia, 2006). The results of soil chemical analysis for each year are shown in Table 1. Tebuconazole fungicide was applied for the control of shoot disease, during the development cycle.

Chemical composition of white oat grains was evaluated as to the contents of protein, lipid, and nitrogen-free extract in the caryopsis. For these analyses, samples of 300 manually dehulled grains (length larger than $2 \mathrm{~mm}$ ) were used. These grains were collected with a bulk harvest in each plot. Caryopses were ground in a Willey type mill with $0.25 \mathrm{~mm}$ sieve opening. Milled material was analyzed by a near-infrared reflectance spectrophotometer (NIRS) model 5000 (Perstorp Analytical Co., Maryland, USA). Calibration curves for the determination of chemical quality traits was obtained using the software NIRSystem (Infrasoft International, 1996), considering the analysis of 100 samples, following the recommendations of Cunniff (1995) and American Association of Cereal Chemists (1996). The protein value was obtained from the nitrogen content in the samples, using the correction factor of 6.25. NIRS readings were performed in triplicate and the results were expressed in dry weight basis ( $\mathrm{g}$ per $100 \mathrm{~g}$ ).

Analysis of variance was performed to identify the effects of cultivar, year, location, and of the interaction between these factors. Adaptability and stability parameters were estimated according to 
Cruz et al. (1989) model, based on the bissegmented linear regression. This procedure has the average $\left(\beta_{\mathrm{oi}}\right)$ and the linear performance in unfavorable $\left(\beta_{1 \mathrm{i}}\right)$ and favorable environments $\left(\beta_{1 \mathrm{i}}+\beta_{2 \mathrm{i}}\right)$ as adaptability parameters. The genotype stability is evaluated by the regression deviation $\left(\sigma_{\delta i}^{2}\right)$ regarding environmental variations, according to the model,

$$
\mathrm{Y}_{\mathrm{ij}}=\beta_{\mathrm{oi}}+\beta_{1 \mathrm{i}} \mathrm{I}_{\mathrm{j}}+\beta_{2 \mathrm{i}} \mathrm{T}\left(\mathrm{I}_{\mathrm{j}}\right)+\delta_{\mathrm{ij}}+\bar{\varepsilon}_{\mathrm{ij}},
$$

in which: $Y_{i j}$ corresponds to the average of genotype $i$ in the $j$ environment; $\beta_{\mathrm{oi}}$ is the general average of genotype $i$ over all tested environments; $\beta_{1 \mathrm{i}}$ is the linear regression coefficient which evaluates the response of $i^{\text {th }}$ genotype to the variation of unfavorable environments; $I_{j}$ is the coded environmental index; $\beta_{2 \mathrm{i}}$ is the linear regression coefficient which evaluates the $i^{\text {th }}$ genotype response to the variation of favorable environments; $\mathrm{T}\left(\mathrm{I}_{\mathrm{j}}\right)=0$, if $I_{j}>0$, or $T\left(I_{j}\right)=I_{j}+I_{+}$, if $I_{j}>0$, being $I_{+}$the average of $\mathrm{I}_{\mathrm{j}}$ positive indexes; $\delta_{\mathrm{ij}}$ is the regression deviations of genotype $\mathrm{i}$ in the environment $\mathrm{j}$; and $\bar{\varepsilon}_{\mathrm{ij}}$ is the average experimental error. The means were compared with the Scott-Knott test, at 5\% probability, in order to analyze the performance of genotypes in different crop seasons and cultivation sites. Additionally, the broad sense heritability $\left(\mathrm{h}_{\mathrm{a}}{ }^{2}\right)$, evidenced by the means of the characters in each environment tested, was determined according to Carvalho et al. (2001). All statistical procedures were performed with the aid of Genes software (Cruz, 2006).

\section{Results and Discussion}

Triple interaction between genotypes (G), cultivation year (Y), and locations (L) was significant for all evaluated traits, except lipid contents (Table 2). No significant interaction between genotypes and locations was detected for the contents of protein and nitrogen-free extract (NFE). Further interactions between traits were all significant, as well as the effects of the major factors (G, Y, and L). According to these results, cultivars varied as to their contents of protein, lipid and NFE in the caryopsis, and the average performance of these traits is affected differently by the tested years and cultivation sites.

The highest mean square for lipid content was found for the cultivar effect (Table 2), indicating that genotype has a major role on the phenotypic expression of this trait, which agrees with Peterson et al. (2005). However, for the contents of protein and NFE, the highest mean squares were determined for cultivation year, followed by Y x L interaction. Beber et al. (2002) reported average values of 16.80 and $6.84 \mathrm{~g}$ per $100 \mathrm{~g}$ for the contents protein and lipid, respectively, in Brazilian oat cultivars. This is slightly lower than those observed in the present work, which were 18.71 and $7.88 \mathrm{~g}$ per $100 \mathrm{~g}$.

Cultivar performances varied over the years and the cultivation sites (Figure 1 and 2). Lipid contents did not differ significantly over the years in many cultivars, in each location. This can be clearly observed in Capão do Leão and Passo Fundo. However, the contents of protein and NFE varied considerably between cultivars over the crop seasons in these locations.

In general, white oat stands out for its high level of proteins of excellent nutritional value, with balanced amino acid profile and high digestibility (Beber et al., 2002; Zhu et al., 2004). The highest mean performance for protein content was observed

Table 1. Soil chemical properties and meteorological conditions in three cultivation sites in the state of Rio Grande do Sul, Brazil.

\begin{tabular}{|c|c|c|c|c|c|c|c|c|c|c|}
\hline \multirow[t]{2}{*}{ Crop season } & \multirow[t]{2}{*}{ Location } & Clay & OM & \multirow{2}{*}{$\begin{array}{l}\text { SMP } \\
\text { index }\end{array}$} & \multirow{2}{*}{\multicolumn{2}{|c|}{$\begin{array}{c}\mathrm{P} \\
\mathrm{K}\end{array}$}} & \multicolumn{3}{|c|}{ Temperature $\left({ }^{\circ} \mathrm{C}\right)^{(1)}$} & \multirow{2}{*}{$\begin{array}{c}\text { Precipitation } \\
(\mathrm{mm})\end{array}$} \\
\hline & & \multicolumn{2}{|c|}{--------(\%) ---------- } & & & & Maximum & Mininum & Mean & \\
\hline \multirow{3}{*}{2007} & Augusto Pestana & 50.0 & 3.2 & 6.6 & 31.0 & 385.0 & 23.3 & 11.4 & 17.3 & 863.0 \\
\hline & Capão do Leão & 24.0 & 2.2 & 6.8 & 29.1 & 143.0 & 19.5 & 10.8 & 15.7 & 798.8 \\
\hline & Passo Fundo & 56.0 & 5.5 & 5.4 & 15.0 & 183.8 & 21.3 & 11.3 & 16.3 & $1,263.5$ \\
\hline \multirow{3}{*}{2008} & Augusto Pestana & 54.0 & 2.9 & 6.2 & 26.0 & 292.0 & 23.1 & 11.3 & 17.2 & 963.6 \\
\hline & Capão do Leão & 16.0 & 1.5 & 6.8 & 8.6 & 64.0 & 20.4 & 11.7 & 16.0 & 575.3 \\
\hline & Passo Fundo & 46.0 & 3.3 & 6.0 & 5.0 & 204.0 & 20.7 & 11.5 & 16.1 & $1,118.8$ \\
\hline \multirow{3}{*}{2009} & Augusto Pestana & 56.0 & 2.8 & 6.4 & 25.0 & 215.0 & 22.8 & 9.7 & 16.2 & $1,407.4$ \\
\hline & Capão do Leão & 21.0 & 2.1 & 6.5 & 19.7 & 80.0 & 20.0 & 11.0 & 15.0 & 952.0 \\
\hline & Passo Fundo & 57.4 & 5.4 & 5.4 & 15.1 & 186.0 & 20.5 & 11.3 & 15.4 & $1,425.7$ \\
\hline
\end{tabular}

${ }^{(1)}$ Data concerning the period from June to November of each year. OM, soil organic matter. 
Table 2. Analysis of variance for the contents of protein, lipid, and nitrogen-free extract (NFE) in the caryopsis, measured in 15 white oat cultivars grown in three municipalities of the state of Rio Grande do Sul, Brazil, in the crop seasons of 2007, 2008, and 2009.

\begin{tabular}{lcccc}
\hline Source of variation & Df & \multicolumn{3}{c}{ Mean square } \\
\cline { 2 - 5 } & & Protein & Lipid & NFE \\
\hline Genotype (G) & 14 & $13.309^{* *}$ & $7.703^{* *}$ & $43.496^{* *}$ \\
Year (Y) & 2 & $153.029^{* *}$ & $4.799^{* *}$ & $817.798^{* *}$ \\
Location (L) & 2 & $22.663^{* *}$ & $3.713^{* *}$ & $19.735^{* *}$ \\
G x Y & 28 & $2.177^{* *}$ & $0.545^{* *}$ & $6.391^{* *}$ \\
G x L & 28 & $0.817^{\text {ns }}$ & $0.539^{* *}$ & $2.899^{\text {ns }}$ \\
Y x L & 4 & $94.192^{* *}$ & $5.750^{* *}$ & $101.253^{* *}$ \\
G x Y x L & 46 & $2.507^{* *}$ & $0.321^{\text {ns }}$ & $5.459^{* *}$ \\
Block & 3 & 2.309 & 0.045 & 6.057 \\
\hline Error & 402 & 0.917 & 0.257 & 2.634 \\
\hline Average (g per 100 g) & - & 18.709 & 7.877 & 67.563 \\
Standard deviation & - & 0.958 & 0.507 & 1.623 \\
CV (\%) & - & 5.118 & 6.437 & 2.402 \\
\hline
\end{tabular}

ns Nonsignificant. ** and *Significant at 1 and $5 \%$ probability, respectively, by the $\mathrm{F}$ test. $\mathrm{CV}$, coeficient of variation.

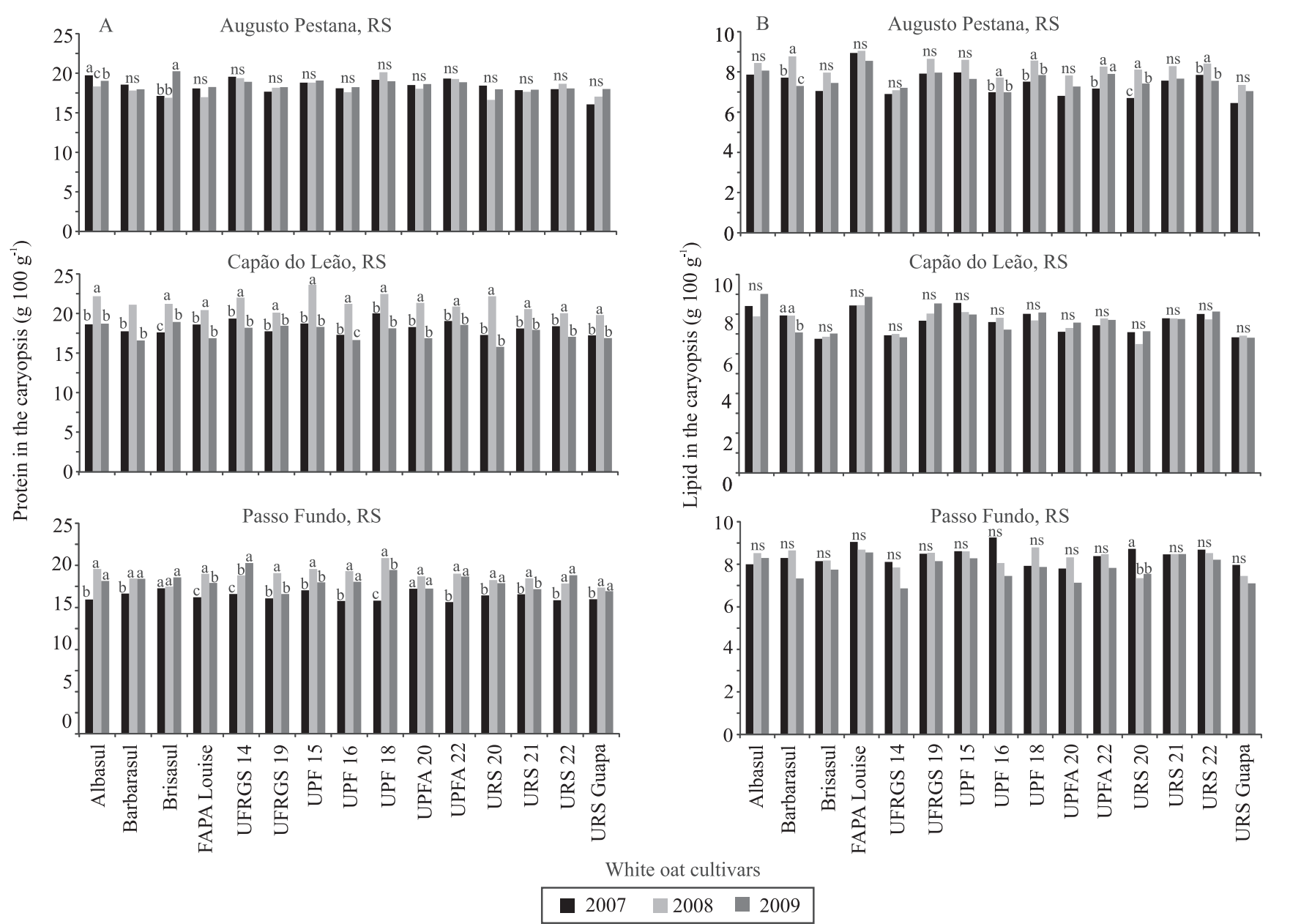

Figure 1. Performance of white oat cultivars in relation to the contents of protein (A), and lipid (B) in the caryopsis

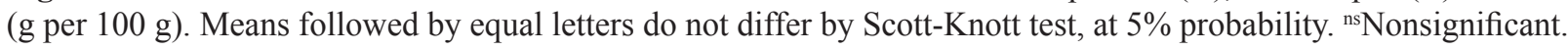

in the cultivars UPF $18(19.80 \mathrm{~g}$ per $100 \mathrm{~g})$, UFRGS 14 (19.58 g per $100 \mathrm{~g})$, UPF 15 (19.44 g per $100 \mathrm{~g})$, Albasul (19.25 g per $100 \mathrm{~g})$, and UPFA 22 (19.14 g per $100 \mathrm{~g}$ ) (Table 3). These cultivars can represent important sources of positive genes to increase grain protein in breeding programs for improving grain chemical quality. However, when it comes to cultivar recommendations, it is important to emphasize that these genotypes had variable adaptability and stability for this trait. Cultivars UPF 18, Albasul and UPFA 22 did not show adaptability to both unfavorable and favorable environments, since their $\beta_{1 \mathrm{i}}$ values were equal or higher than 1.0 , and their $\beta_{1 \mathrm{i}}+\beta_{2 \mathrm{i}}$ values were equal or smaller than 1.0. According to Cruz et al. (1989), the model $\beta_{1 \mathrm{i}}<1.0$ represents adaptability to unfavorable environments, and $\beta_{1 \mathrm{i}}$ $+\beta_{2 \mathrm{i}}>1.0$ corresponds to adaptability to favorable 
environments. The cultivars URS 20 and UPFA 15 were adapted to favorable environments, and Brisasul, UFRGS 19, and URS 21, to unfavorable environments. However, the cultivars Brisasul and UFRGS 19, together with UPF 18 and URS 20, were unstable, i.e, they showed significant regression deviations $\left(\sigma_{\delta \mathrm{i}}^{2} \neq 0\right)$, which indicate unpredictable behavior across the environments. The lowest mean protein content was shown by 'URS Guapa' $(17.60 \mathrm{~g}$ per $100 \mathrm{~g})$, which was stable in the tested environments.

The lowest environment index $\left(\mathrm{I}_{\mathrm{j}}\right)$ for protein content (-1.44) was detected in 2007, in Passo Fundo, where the lowest average performance (17.27 g per $100 \mathrm{~g}$ ) occurred (Table 4). The highest mean was

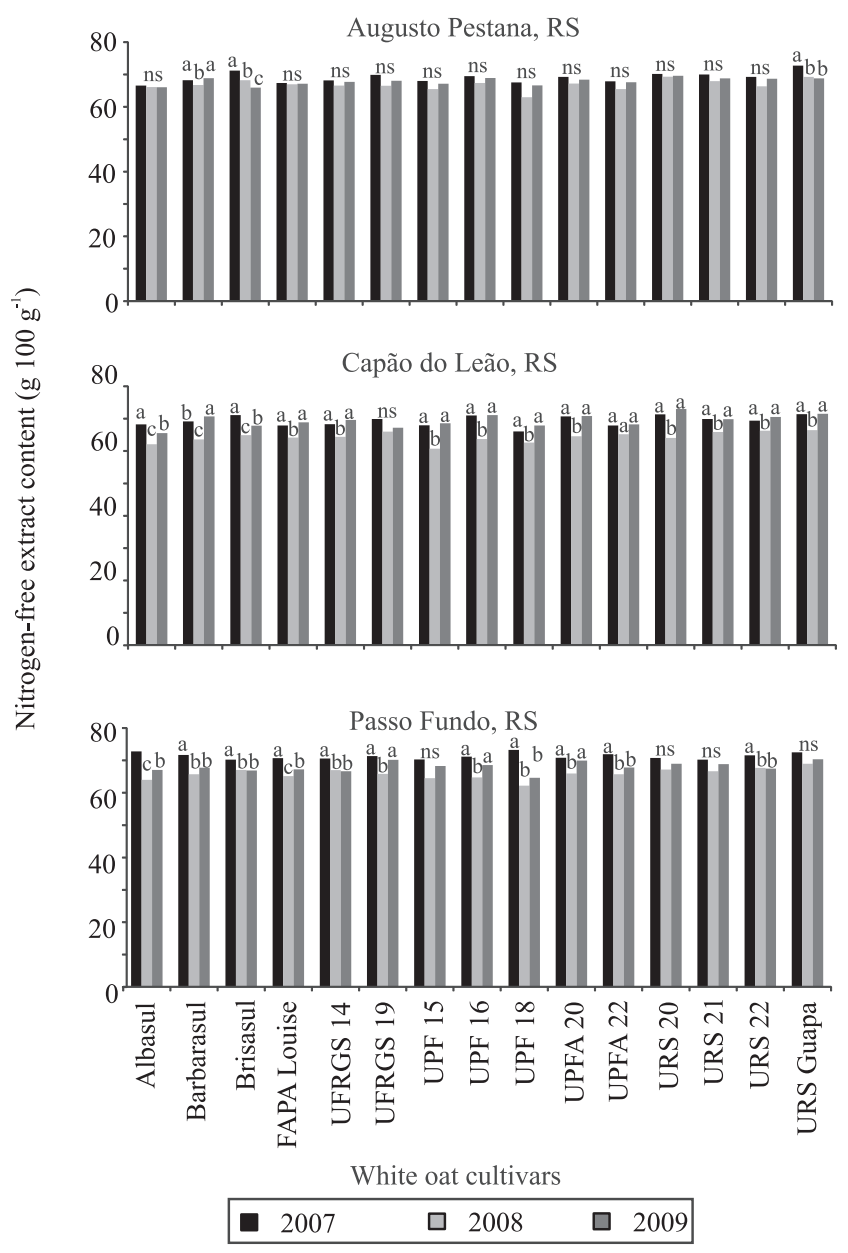

Figure 2. Performance of white oat cultivars as to the nitrogen-free extract contents in the caryopsis (g per $100 \mathrm{~g}$ ). Means followed by equal letters do not differ by Scott-Knott

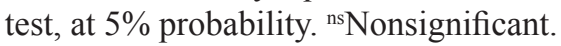

obtained in Capão do Leão, in $2008\left(\mathrm{I}_{\mathrm{j}}=2.55 ; 21.26 \mathrm{~g}\right.$ per $100 \mathrm{~g}$ ).

According to the model of Cruz et al. (1989), an ideal genotype would be a cultivar which concomitantly shows high protein content $\left(\beta_{\mathrm{oi}}\right)$, adaptability to unfavorable $\left(\beta_{1 \mathrm{i}}<1.0\right)$ and favorable environments $\left(\beta_{1 \mathrm{i}}+\beta_{2 \mathrm{i}}>1.0\right)$, and stability $\left(\sigma_{\delta \mathrm{i}}^{2}=0\right)$. No ideal genotype was found among the analyzed cultivars, which met these criteria.

As to lipid content in the caryopsis, cultivars URS Guapa and UFRGS 14 showed the lowest performance (7.12 and $7.22 \mathrm{~g}$ per $100 \mathrm{~g}$, respectively) while the highest average were found in FAPA Louise (8.77 g per $100 \mathrm{~g}$ ) (Table 3$)$. Only 'URS 20' was adapted to favorable environments. However, this cultivar had an unstable behavior, along with Albasul, Barbarasul and UPF 16. The lowest environment index for genotype performance as to lipid content was detected in 2007, in Augusto Pestana $\left(I_{j}=-0.45\right)$, where the lowest average performance $(7.43 \mathrm{~g}$ per $100 \mathrm{~g})$ was observed (Table 4). The best favorable environment was Augusto Pestana, in $2008\left(\mathrm{I}_{\mathrm{j}}=0.33\right.$, average of $8.21 \mathrm{~g}$ per $100 \mathrm{~g}$ ).

Nitrogen-free extract had an overall average performance of $67.56 \mathrm{~g}$ per $100 \mathrm{~g}$, ranging from 65.54 to $69.75 \mathrm{~g}$ per $100 \mathrm{~g}$ (Tables 2 and 3). Gatto (2005) observed a range of NFE contents of 69.8 to $75.7 \mathrm{~g}$ per $100 \mathrm{~g}$, in the caryopses of 22 Brazilian white oat genotypes grown in Southern Brazil. 'Albasul' and 'UPF 18 ' were adapted only to favorable environments. However, these cultivars showed low performance (66.04 and $65.54 \mathrm{~g}$ per $100 \mathrm{~g}$, respectively) and low stability. Higher performance was shown by 'URS Guapa' (69.75 g per $100 \mathrm{~g}$ ) and 'URS 20' (68.93 g per $100 \mathrm{~g}$ ); however, they showed low adaptability, and the cultivars URS 20, Brisasul and UFRGS 19 had low stability as well. The lowest environment index for nitrogen-free extract was observed in 2008, in Capão do Leão $\left(\mathrm{I}_{\mathrm{j}}=-3.64 ; 63.93 \mathrm{~g}\right.$ per $100 \mathrm{~g}$ ), and the best favorable environment was Augusto Pestana $\left(\mathrm{I}_{\mathrm{j}}=2.77 ; 70.33 \mathrm{~g}\right.$ per $\left.100 \mathrm{~g}\right)$ in 2007 (Table 4).

Alternative models of stability and adaptability analysis adopting nonparametric methods have been used for genotype evaluations of autogamous annual species (Backes et al., 2005; Amorin et al., 2006; Elias et al., 2007). These methods can represent effective alternatives to evaluate the stability and 
Table 3. General averages $\left(\mathrm{b}_{0}\right.$; $\mathrm{g}$ per $100 \mathrm{~g}$ ) of protein, lipid, and nitrogen-free extract content in the caryopsis and parameters of adaptability $\left(b_{1},\left(b_{1}+b_{2}\right)\right)$ and stability $\left(\sigma_{\delta i}^{2}\right)$ according to Cruz et al. (1989) model, in white oat cultivars grown in three municipalities of the state of Rio Grande do Sul, Brazil, in the crop seasons of 2007, 2008, and 2009(1).

\begin{tabular}{|c|c|c|c|c|c|c|c|}
\hline Cultivar & $\mathrm{b}_{0}$ & Average (U) & Average (F) & $\mathrm{b}_{1}$ & $\mathrm{~b}_{1}+\mathrm{b}_{2}$ & $\sigma_{\delta \mathrm{i}}^{2}$ & $\mathrm{R}^{2}$ \\
\hline & \multicolumn{7}{|c|}{ Protein content in the caryopsis } \\
\hline Albasul & $19.25 \mathrm{a}$ & 18.54 & 20.68 & $1.09^{\text {ns }}$ & $1.38^{\mathrm{ns}}$ & $1.50^{\mathrm{ns}}$ & 87.68 \\
\hline Barbarasul & $18.48 \mathrm{~b}$ & 17.71 & 20.01 & $1.07^{\mathrm{ns}}$ & $0.84^{\mathrm{ns}}$ & $1.01^{\mathrm{ns}}$ & 89.54 \\
\hline Brisasul & $18.71 \mathrm{~b}$ & 18.18 & 19.77 & $0.69 *$ & $0.93^{\mathrm{ns}}$ & $6.70^{* *}$ & 39.81 \\
\hline FAPA Louise & $18.37 \mathrm{~b}$ & 17.65 & 19.81 & $1.05^{\mathrm{ns}}$ & $0.64^{\mathrm{ns}}$ & $1.01^{\mathrm{ns}}$ & 88.57 \\
\hline UFRGS 14 & $19.58 \mathrm{a}$ & 18.82 & 21.10 & $1.13^{\mathrm{ns}}$ & $0.45^{\text {ns }}$ & $1.91^{\mathrm{ns}}$ & 82.09 \\
\hline UFRGS 19 & $18.34 \mathrm{~b}$ & 17.87 & 19.27 & $0.64 *$ & $1.03^{\mathrm{ns}}$ & $2.17 *$ & 66.70 \\
\hline UPF 15 & $19.44 \mathrm{a}$ & 18.62 & 21.10 & $1.14^{\mathrm{ns}}$ & $2.19 * *$ & $0.16^{\mathrm{ns}}$ & 99.03 \\
\hline UPF 16 & $18.36 \mathrm{~b}$ & 17.42 & 20.23 & $1.34 *$ & $0.95^{\mathrm{ns}}$ & $0.44^{\mathrm{ns}}$ & 96.81 \\
\hline UPF 18 & $19.80 \mathrm{a}$ & 18.85 & 21.69 & $1.45 * *$ & $0.81^{\mathrm{ns}}$ & $2.76^{* *}$ & 84.26 \\
\hline UPFA 20 & $18.64 \mathrm{~b}$ & 18.08 & 19.77 & $0.80^{\mathrm{ns}}$ & $1.44^{\mathrm{ns}}$ & $1.01^{\mathrm{ns}}$ & 87.97 \\
\hline UPFA 22 & $19.14 \mathrm{a}$ & 18.60 & 20.23 & $0.90^{\mathrm{ns}}$ & $0.53^{\mathrm{ns}}$ & $1.89^{\mathrm{ns}}$ & 75.46 \\
\hline URS 20 & $18.20 \mathrm{~b}$ & 17.24 & 20.12 & $1.34 *$ & $1.64 *$ & $2.36^{*}$ & 87.07 \\
\hline URS 21 & $18.35 b$ & 17.82 & 19.40 & $0.70 *$ & $1.08^{\mathrm{ns}}$ & $0.41^{\mathrm{ns}}$ & 92.31 \\
\hline URS 22 & $18.41 \mathrm{~b}$ & 17.82 & 19.59 & $0.91^{\mathrm{ns}}$ & $0.17 * *$ & $1.23^{\mathrm{ns}}$ & 81.58 \\
\hline \multirow[t]{2}{*}{ URS Guapa } & $17.60 \mathrm{c}$ & 17.02 & 18.68 & $0.75^{\text {ns }}$ & $0.92^{\mathrm{ns}}$ & $1.34^{\mathrm{ns}}$ & 78.64 \\
\hline & \multicolumn{7}{|c|}{ Lipid content in the caryopsis } \\
\hline Albasul & $8.32 b$ & 7.97 & 8.49 & $0.94^{\mathrm{ns}}$ & $1.09^{\mathrm{ns}}$ & $1.18^{* *}$ & 25.42 \\
\hline Barbarasul & $7.92 \mathrm{c}$ & 7.36 & 8.20 & $1.43^{\mathrm{ns}}$ & $0.52^{\mathrm{ns}}$ & $0.90^{* *}$ & 49.03 \\
\hline Brisasul & $7.48 \mathrm{~d}$ & 7.32 & 7.56 & $0.46^{\mathrm{ns}}$ & $2.27^{\mathrm{ns}}$ & $0.40^{\mathrm{ns}}$ & 36.19 \\
\hline FAPA Louise & $8.77 \mathrm{a}$ & 8.58 & 8.86 & $0.46^{\mathrm{ns}}$ & $1.95^{\mathrm{ns}}$ & $0.43^{\mathrm{ns}}$ & 30.50 \\
\hline UFRGS 14 & $7.22 \mathrm{e}$ & 6.91 & 7.38 & $0.88^{\mathrm{ns}}$ & $1.19^{\mathrm{ns}}$ & $0.29^{\text {ns }}$ & 55.14 \\
\hline UFRGS 19 & $8.25 b$ & 7.91 & 8.42 & $0.91^{\mathrm{ns}}$ & $1.98^{\mathrm{ns}}$ & $0.29^{\mathrm{ns}}$ & 60.40 \\
\hline UPF 15 & $8.30 \mathrm{~b}$ & 7.87 & 8.51 & $1.09^{\mathrm{ns}}$ & $0.04^{\mathrm{ns}}$ & $0.34^{\mathrm{ns}}$ & 59.72 \\
\hline UPF 16 & $7.70 \mathrm{~d}$ & 7.05 & 8.03 & $1.72 *$ & $1.04^{\mathrm{ns}}$ & $0.81 * *$ & 61.11 \\
\hline UPF 18 & $8.06 \mathrm{c}$ & 7.65 & 8.27 & $1.15^{\mathrm{ns}}$ & $0.98^{\mathrm{ns}}$ & $0.42^{\mathrm{ns}}$ & 58.00 \\
\hline UPFA 20 & $7.49 \mathrm{~d}$ & 6.98 & 7.74 & $1.40^{\mathrm{ns}}$ & $0.38^{\mathrm{ns}}$ & $0.20^{\mathrm{ns}}$ & 80.34 \\
\hline UPFA 22 & $7.91 \mathrm{c}$ & 7.54 & 8.10 & $1.08^{\mathrm{ns}}$ & $0.60^{\mathrm{ns}}$ & $0.18^{\mathrm{ns}}$ & 74.03 \\
\hline URS 20 & $7.42 \mathrm{~d}$ & 7.13 & 7.56 & $0.84^{\mathrm{ns}}$ & $5.24 * *$ & $0.62 *$ & 62.29 \\
\hline URS 21 & $8.06 \mathrm{c}$ & 7.80 & 8.18 & $0.69^{\text {ns }}$ & $0.38^{\mathrm{ns}}$ & $0.14^{\mathrm{ns}}$ & 58.34 \\
\hline URS 22 & $8.15 b$ & 7.77 & 8.34 & $0.97^{\mathrm{ns}}$ & $1.20^{\mathrm{ns}}$ & $0.13^{\text {ns }}$ & 76.78 \\
\hline \multirow[t]{2}{*}{ URS Guapa } & $7.12 \mathrm{e}$ & 6.78 & 7.30 & $0.99^{\text {ns }}$ & $0.69^{\mathrm{ns}}$ & $0.19^{\mathrm{ns}}$ & 69.31 \\
\hline & \multicolumn{7}{|c|}{ Nitrogen-free extract content in the caryopsis } \\
\hline Albasul & $66.04 \mathrm{~d}$ & 64.26 & 67.47 & $1.07^{\mathrm{ns}}$ & $2.41^{* *}$ & $7.29 *$ & 83.03 \\
\hline Barbarasul & $67.60 \mathrm{~b}$ & 65.39 & 69.37 & $1.18^{\mathrm{ns}}$ & $0.78^{\mathrm{ns}}$ & $1.92^{\mathrm{ns}}$ & 94.08 \\
\hline Brisasul & $67.71 \mathrm{~b}$ & 66.21 & 68.91 & $0.79^{\text {ns }}$ & $1.26^{\mathrm{ns}}$ & $12.09 * *$ & 57.44 \\
\hline FAPA Louise & $66.82 \mathrm{c}$ & 65.32 & 68.03 & $0.85^{\mathrm{ns}}$ & $1.07^{\mathrm{ns}}$ & $1.22^{\mathrm{ns}}$ & 93.49 \\
\hline UFRGS 14 & $67.22 \mathrm{c}$ & 65.60 & 68.52 & $0.80^{\text {ns }}$ & $0.77^{\mathrm{ns}}$ & $2.14^{\mathrm{ns}}$ & 87.40 \\
\hline UFRGS 19 & $67.87 \mathrm{~b}$ & 66.55 & 68.92 & $0.76^{\mathrm{ns}}$ & $0.97^{\mathrm{ns}}$ & $6.90^{*}$ & 67.02 \\
\hline UPF 15 & $66.33 \mathrm{~d}$ & 64.20 & 68.04 & $1.31 *$ & $0.91^{\mathrm{ns}}$ & $3.29^{\text {ns }}$ & 92.01 \\
\hline UPF 16 & $68.00 \mathrm{~b}$ & 65.54 & 69.97 & $1.36^{*}$ & $0.47^{\mathrm{ns}}$ & $1.55^{\mathrm{ns}}$ & 96.19 \\
\hline UPF 18 & $65.54 \mathrm{~d}$ & 62.57 & 67.92 & $1.37 *$ & $2.43^{* *}$ & $10.36^{* *}$ & 83.14 \\
\hline UPFA 20 & $68.17 \mathrm{~b}$ & 66.34 & 69.64 & $1.07^{\mathrm{ns}}$ & $0.52^{\mathrm{ns}}$ & $2.56^{\mathrm{ns}}$ & 90.60 \\
\hline UPFA 22 & $67.08 \mathrm{c}$ & 65.49 & 68.35 & $0.79^{\text {ns }}$ & $1.43^{\mathrm{ns}}$ & $2.51^{\mathrm{ns}}$ & 87.19 \\
\hline URS 20 & $68.93 \mathrm{a}$ & 66.80 & 70.63 & $1.23^{\mathrm{ns}}$ & $0.01^{*}$ & $5.72 *$ & 84.76 \\
\hline URS 21 & $68.24 \mathrm{~b}$ & 66.78 & 69.41 & $0.80^{\text {ns }}$ & $0.16^{\mathrm{ns}}$ & $0.64^{\mathrm{ns}}$ & 95.51 \\
\hline URS 22 & $68.13 b$ & 66.38 & 69.52 & $0.76^{\mathrm{ns}}$ & $0.77^{\mathrm{ns}}$ & $3.15^{\mathrm{ns}}$ & 80.90 \\
\hline URS Guapa & $69.75 \mathrm{a}$ & 68.17 & 71.02 & $0.88^{\text {ns }}$ & $1.06^{\mathrm{ns}}$ & $3.54^{\mathrm{ns}}$ & 83.95 \\
\hline
\end{tabular}

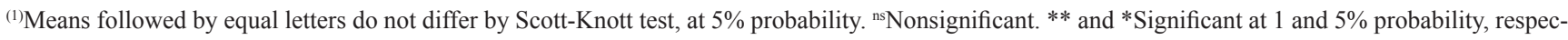
tively, by t test. (U), unfavorable environment; (F), favorable environment. 
adaptability of genotypes and show advantages over parametric models: reduction of the tendentiousness caused by points way out of the fitted regression; no assumption requirement about the characteristics of the phenotypic value distribution; parameters are easy to use and interpret; and low sensibility to the addition or removal of one or few genotypes from the analysis (Cruz, 2006).

There is little information about environmental effects that can interfere in the NFE contents of oat grains. Much of this fraction is formed by starch, which correspond to nearly $60 \%$ dry matter of the oat grain (Liu et al., 2010). Rhymer et al. (2005) observed that the environment was the dominant factor contributing to the total variation in starch contents of oat genotypes. Many reports indicate that environmental effects may interfere in the protein and oil contents in the oat caryopsis (Beber et al., 2002; Zhu et al., 2004; Peterson et al., 2005; Martinez et al., 2010). Humphreys et al. (1994) and by Kolchinski \& Schuch $(2003,2004)$ reported that application of nitrogen fertilizer increases protein content in the grains, and decreases oil content. Moreover, temperature variation during oat development may have great influence on lipid synthesis in the grain. According to Martinez et al. (2010), the increase of total lipid content is favored by lower temperatures and, in these conditions, the synthesis of unsaturated lipids and the level of unsaturation are increased.
Despite the amplitude in the performance observed in the chemical composition of white oat caryopsis (Figure 1 and 2), a general behavior can be noticed along favorable and unfavorable environments (Table 4). In general, cultivars characterized by a higher or a lower average performance for a specific character tended to have this behavior in both environmental conditions. The highest amplitudes were observed for protein contents, in which the average performance of cultivars was $7.7 \%$ lower than the overall average, in unfavorable environment, and $13.6 \%$ higher than the overall average, in the most favorable environment. For the contents of lipid and NFE, variation was close to $5 \%$ on the overall average. Passo Fundo in 2007 and Augusto Pestana in 2009 represented the environments with the most effect on the genotypes performance, which was evidenced by the lowest heritabilities $(<50 \%)$ observed for all evaluated characters. However, in general, the heritabilities found were of high magnitude, higher than $70 \%$ in seven of the nine tested environments, suggesting that the genetic variance played a major role in the phenotypic variance.

There are evidences in the literature that these traits have polygenic inheritance, with strong contribution of additive effects, and that the environmental contribution for the phenotypic definition vary (Zhu et al., 2004; Orr \& Molnar, 2007; Crestani et al., 2012).

Table 4. General averages $\left(\mathrm{b}_{0}\right.$; g per $\left.100 \mathrm{~g}\right)$ of protein, lipid, and nitrogen-free extract content in the caryopsis, environment index $\left(\mathrm{I}_{\mathrm{j}}\right)$ according to Cruz et al. (1989) model, and broad sense heritability $\left(\mathrm{h}_{\mathrm{a}}^{2}\right)$ in white oat cultivars grown in three municipalities of the state of Rio Grande do Sul, Brazil, in the crop seasons of 2007, 2008, and 2009.

\begin{tabular}{|c|c|c|c|c|c|c|c|c|c|}
\hline \multirow[t]{2}{*}{ Season } & \multicolumn{3}{|c|}{ Augusto Pestana } & \multicolumn{3}{|c|}{ Capão do Leão } & \multicolumn{3}{|c|}{ Passo Fundo } \\
\hline & Average & $\mathrm{I}_{\mathrm{j}}$ & $h_{a}^{2}(\%)$ & Average & $\mathrm{I}_{\mathrm{j}}$ & $\mathrm{h}_{\mathrm{a}}^{2}(\%)$ & Average & $\mathrm{I}_{\mathrm{j}}$ & $\mathrm{h}_{\mathrm{a}}^{2}(\%)$ \\
\hline & \multicolumn{9}{|c|}{ Protein content in the caryopsis } \\
\hline 2007 & 18.33 & $0.38(\mathrm{U})$ & 79.85 & 18.26 & $-0.45(\mathrm{U})$ & 74.34 & 17.27 & $-1.44(U)$ & 31.13 \\
\hline 2008 & 18.10 & $-0.61(\mathrm{U})$ & 91.97 & 21.26 & $2.55(\mathrm{~F})$ & 80.27 & 19.85 & $1.14(\mathrm{~F})$ & 81.52 \\
\hline \multirow[t]{2}{*}{2009} & 18.56 & $-0.15(\mathrm{U})$ & 40.91 & 17.58 & $-1.13(\mathrm{U})$ & 83.32 & 19.17 & $0.47(\mathrm{~F})$ & 90.74 \\
\hline & \multicolumn{9}{|c|}{ Lipid content in the caryopsis } \\
\hline 2007 & 7.43 & $-0.45(\mathrm{U})$ & 91.93 & 8.02 & $0.14(\mathrm{~F})$ & 89.93 & 8.08 & $0.21(\mathrm{~F})$ & 30.13 \\
\hline 2008 & 8.21 & $0.33(\mathrm{~F})$ & 94.91 & 7.96 & $0.09(\mathrm{~F})$ & 93.03 & 7.99 & $0.12(\mathrm{~F})$ & 72.77 \\
\hline \multirow[t]{2}{*}{2009} & 7.59 & $-0.28(\mathrm{U})$ & 48.34 & 8.10 & $0.23(\mathrm{~F})$ & 92.73 & 7.50 & $-0.38(U)$ & 77.49 \\
\hline & \multicolumn{9}{|c|}{ Nitrogen-free extract content in the caryopsis } \\
\hline 2007 & 69.06 & $1.49(\mathrm{~F})$ & 84.41 & 68.94 & $1.38(\mathrm{~F})$ & 85.29 & 70.33 & $2.77(\mathrm{~F})$ & 35.59 \\
\hline 2008 & 66.84 & $-0.72(U)$ & 89.33 & 63.93 & $-3.64(U)$ & 75.90 & 64.98 & $-2.59(U)$ & 79.66 \\
\hline 2009 & 67.90 & $0.34(\mathrm{~F})$ & 24.58 & 69.01 & $1.45(\mathrm{~F})$ & 87.17 & 67.09 & $-0.48(U)$ & 71.52 \\
\hline
\end{tabular}

(U), unfavorable environment; (F), favorable environment. 


\section{Conclusions}

1. White oat performance as to grain chemical composition is affected by cultivation site, crop season, and genotypes.

2. There is no ideal genotype, among the evaluated cultivars, with high average performance, high adaptability, and high stability, simultaneously.

\section{References}

AMERICAN ASSOCIATION OF CEREAL CHEMISTS. Approved methods. $9^{\text {th }}$ ed. Saint Paul: AACC, 1996.

AMORIM, E.P.; CAMARGO, C.E. de O.; FERREIRA FILHO, A.W.P.; PETTINELLI JUNIOR, A.; GALLO, P.B.; AZEVEDO FILHO, J.A. Adaptabilidade e estabilidade de linhagens de trigo no Estado de São Paulo. Bragantia, v.65, p.575-582, 2006. DOI: 10.1590/S0006-87052006000400007.

BACKES, R.L.; ELIAS, H.T.; HEMP, S.; NICKNICH, W. Adaptabilidade e estabilidade de genótipos de feijoeiro no Estado de Santa Catarina. Acta Scientiarum. Agronomy, v.27, p.309-314, 2005.

BEBER, R.C.; FRANCISCO, A.; ALVES, A.C.; SÁ, R.M. de; OGLIARI, P. Caracterização química de genótipos brasileiros de aveia (Avena sativa L.). Acta Cientifica Venezolana, v.53, p.202-209, 2002.

CARVALHO, F.I.F.; SILVA, S.A.; KUREK, A.J.; MARCHIORO, V.S. Estimativas e implicações da herdabilidade como estratégia de seleção. Pelotas: UFPel, 2001. 99p.

COMISSÃO BRASILEIRA DE PESQUISA DE AVEIA. Indicações técnicas para cultura da aveia. Guarapuava: Fundação Agrária de Pesquisa Agropecuária, 2006. 82p.

CHERNYSHOVA, A.A.; WHITE, P.J.; SCOTT, M.P.; JANNINK, J.L. Selection for nutritional function and agronomic performance in oat. Crop Science, v.47, p.2330-2339, 2007. DOI: 10.2135/ cropsci2006.12.0759.

CRESTANI, M.; SILVEIRA, S.F.S. da; TESSMANN, E.W.; MEZZALIRA, I.; LUCHE, H. de S.; SILVA, J.A.G. da; GUTKOSKI, L.C.; CARVALHO, F.I.F. de; OLIVEIRA, A.C. de. Combining ability for grain chemistry quality traits in a white oat diallelic cross. Euphytica, v.185, p.139-156, 2012. DOI: 10.1007/ s10681-012-0641-0.

CRUZ, C.D. Programa Genes: biometria. Viçosa: UFV, 2006. $382 \mathrm{p}$.

CRUZ, C.D.; REGAZZI, A.J.; CARNEIRO, P.C.S. Modelos biométricos aplicados ao melhoramento genético. Viçosa: UFV, 2004. 480p.

CRUZ, C.D.; TORRES, R. de A.A.; VENCOVSKY, R. An alternative approach to the stability analysis proposed by Silva e Barreto. Revista Brasileira de Genética, v.12, p.567-580, 1989.

CUNNIFF, P. (Ed.). Official methods of analysis of the AOAC International. $16^{\text {th }}$ ed. Arlington: AOAC International, 1995. $2 \mathrm{v}$.
ELIAS, H.T.; BACKES, R.L.; VIDIGAL, M.C.G.; BALBINOT JUNIOR, A.A.; HEMP, S. Estabilidade e adaptabilidade de linhagens e cultivares de feijão do grupo carioca. Scientia Agraria, v.8, p.379-384, 2007.

GATTO, L. Dissimilaridade genética e análise de trilha quanto a características físicas e químicas do grão de aveia branca. 2005. 92p. Dissertação (Mestrado) - Universidade de Passo Fundo, Passo Fundo.

HOLLAND, J.B. Oat improvement. In: KANG, M.S. (Ed.). Crop improvement for the $21^{\text {st }}$ century. Trivandrum: Research Signpost, 1997. p.57-98.

HUMPHREYS, D.G.; SMITH, D.L.; MATHER, D.E. Nitrogen fertilizer and seeding date induced charges in protein, oil and $\beta$-glucan contents of four oat cultivars. Journal of Cereal Science, v.20, p.283-290, 1994. DOI: 10.1006/jcrs.1994.1068.

INFRASOFT INTERNATIONAL. NIRSystems: routine operation and calibration development manual. Version 4.0. Washington: ISI, 1996. 378p.

KOLCHINSKI, E.M.; SCHUCH, L.O.B. Atributos de desempenho industrial e qualidade de sementes em aveia branca em função da disponibilização da adubação nitrogenada. Ciência Rural, v.33, p.587-589, 2003. DOI: 10.1590/S010384782003000300031 .

KOLCHINSKI, E.M.; SCHUCH, L.O.B. Relações entre a adubação nitrogenada e a qualidade de grãos e de sementes em aveia branca. Ciência Rural, v.34, p.379-383, 2004. DOI: 10.1590/ S0103-84782004000200007.

LIU, Y.; BAILEY, T.B.; WHITE, P.J. Individual and interactional effects of $\beta$-glucan, starch, and protein on pasting properties of oat flours. Journal of Agricultural and Food Chemistry, v.58, p.9198-9203, 2010. DOI: 10.1021/jf1007852.

LORENCETTI, C.; CARVALHO, F.I.F. de; ALMEIDA, J.L.; MARCHIORO, V.S.M.; BENIN, G.; HARTWIG, I. Adaptabilidade e estabilidade de rendimento de grãos em aveia hexaplóide. Pesquisa Agropecuária Gaúcha, v.8, p.83-91, 2002. DOI: 10.1590/S0103-84782004000300007.

LORENCETTI, C.; CARVALHO, F.I.F. de; MARCHIORO, V.S.M.; BENIN, G.; OLIVEIRA, A.C. de; FLOSS, E.L. Implicações da aplicação de fungicida na adaptabilidade e estabilidade de rendimento de grãos em aveia branca. Ciência Rural, v.34, p.693-700, 2004. DOI: 10.1590/S010384782004000300007 .

MARINISSEN, J.; ARELOVICH, H.M.; MARTI'NEZ, M.F.; ZILIO, L.; OMBROSI, D. Oats grain supplementation of calves grazing oats pasture. 1. Diet composition, liveweight gain and blood parameters. Revista Argentina de Producción Animal, v.24, p.80-81, 2004.

MARTINEZ, M.F.; ARELOVICH, H.M.; WEHRHAHNE, L.N. Grain yield, nutrient content and lipid profile of oat genotypes grown in a semiarid environment. Field Crops Research, v.116, p.92-100, 2010. DOI: 10.1016/j.fcr.2009.11.018.

ORR, W.; MOLNAR, S.J. Development and mapping of PCR-based SCAR and CAPS markers linked to oil QTLs in oat. Crop Science, v.47, p.848-852, 2007. DOI: 10.2135/cropsci2006.01.0053. 
PETERSON, D.M.; WESENBERG, D.M.; BURRUP, D.E.; ERICKSON, C.A. Relationships among agronomic traits and grain composition in oat genotypes grown in different environments. Crop Science, v.45, p.1249-1255, 2005. DOI: 10.2135/ cropsci2004.0063.

RHYMER, C.; AMES, N.; MALCOLMSON, L.; BROWN, D.; DUGUID, S. Effects of genotype and environment on the starch properties and end-product quality of oats. Cereal Chemistry, v.82, p.197-203, 2005. DOI: 10.1094/CC-82-0197.
SANTOS, H.G. dos; JACOMINE, P.K.T.; ANJOS, L.H.C. dos; OLIVEIRA, V.A. de; OLIVEIRA, J.B. de; COELHO, M.R.; LUMBRERAS, J.F.; CUNHA, T.J.F. (Ed.). Sistema brasileiro de classificação de solos. Rio de Janeiro: Embrapa Solos, 2006. $306 \mathrm{p}$.

ZHU, S.; ROSSNAGEL, B.G.; KAEPPLER, H.F. Genetic analysis of quantitative trait loci for groat protein and oil content in oat. Crop Science, v.44, p.254-260, 2004. DOI: 10.2135/ cropsci2004.0254.

Received on April 14, 2012 and accepted on January 7, 2013 